\title{
Narrativas do tempo em enredos de professores/as*
}

\section{Inês Assunção de Castro Teixeira**}

\author{
"Há muitos tempos dentro do tempo" \\ "Às vezes o tempo não dá tempo"
}

Estes DIZERES DOS PROFEsSORES Lousada e Marisa em suas entrevistas, respectivamente, contêm a temática deste trabalho: os enredos do tempo na condição de professor. Entrelaçada às temporalidades da infância, da juventude e da idade adulta, aos ritmos da construção do conhecimento, da transmissão da memória cultural às novas gerações, às rítmicas da escola presentes nos calendários, horários, agendas, nos currículos e a outras dimensões das temporalidades da escola e de seus

* A discussão que apresentamos neste trabalho e o material empírico (registros de campo e extratos de entrevistas) de que nos valemos para ilustrar a análise, têm origem em minha tese de doutorado intitulada Tempos enredados: teias da condição professor (1998). Trata-se de pesquisa com ênfase qualitativa, realizada em duas escolas públicas de Belo Horizonte, através de observação de campo, questionários e entrevistas com professores/as de quinta a oitava série do Ensino Fundamental e do Ensino Médio, entre julho de 1997 e junho de 1998. Mediante o pressuposto de que o tempo é uma construção sócio-histórica, parte dos sistemas simbólicos das sociedades, constituídos em longas cadeias de gerações e agenciamentos humanos, a tese investiga as processualidades de sua construção social na experiência dos professores. Desenvolve o argumento de que, na condição professor, a experiência do tempo costura-se em fina trama, visto sua peculiar configuração. É uma experiência singular, que engendra modos de ser e de habitar o mundo, identidades sociais e histórias.

* Professora da Faculdade de Educação da UFMG. Professora pesquisadora do Programa de História Oral do Centro de Estudos Mineiros da FAFICH/UFMG 
sujeitos, a experiência do tempo na condição professor é uma complexa e plural arquitetura.

$\mathrm{Na}$ tentativa de compreender alguns de seus contornos e traçados e, sobretudo, as significações que os professores atribuem à experiência do tempo na condição docente, esta vivência é aqui analisada em alguns de seus aspectos e dimensões, num esforço intelectual que pretende temporalizar as relações sociais e sociologizar o tempo, na expressão de Torre (1992). Entendendo a noção de tempo e suas formas de demarcação, de mensuração e de representação como construções sócio-históricas, parte dos sistemas simbólicos de distintas épocas e culturas, sistemas constituídos pelos agenciamentos humanos de longas cadeias de gerações, o trabalho discute alguns aspectos que particularizam a experiência do tempo nas vidas de professores do Ensino Fundamental e Médio, através de suas narrativas em entrevistas e de observação de campo.

Partindo ainda do pressuposto de que a experiência temporal, como toda experiência humana e social, é uma atividade, um "trabalho" dos sujeitos (Dubet, 1994), o estudo discute três dos planos desta complexa experiência, planos inscritos nas configurações do tempo na escola. São então focalizados: os tempos das festas, os tempos das aulas e os tempos interstícios. O primeiro, os tempos das festas, são os momentos de encontros mais espontâneos entre professores e estudantes e, não raro, entre seus familiares e amigos; são as ocasiões de descontração e de inversão de papéis e de lugares, quando os professores se transformam em cantores, dançarinos, vendedores e outros personagens.

Os tempos das aulas são a maior parte do período em que os professores estão na escola desenvolvendo seus trabalhos, momentos em que mantêm relações face-a-face com seus alunos. Trata-se de um período de tensões, de encontros e desencontros, de conflitos, de alegrias e dissabores peculiares à convivência intergeracional e ao trabalho pedagógico nos territórios da escola.

Quanto aos tempos interstícios, referem-se aos recreios, aos intervalos entre uma aula e outra, entre um e outro turno, e aos horários de entrada e de saída da escola, nos quais os docentes se encontram uns com os outros, mais livre e informalmente, em geral sem a presença física dos alunos. São momentos em que falam de suas preocupações e projetos, de alegrias e sofrimentos, esperanças e indignações, dentre 
outras trocas que, nestas ocasiões, os mestres realizam em relação às suas vidas e pessoas.

\section{Tempos especiais: os tempos das festas}

“São 20:45 horas do dia 06 de julho de 1998. O pátio e o corredor central da escola estão cobertos de bandeirinhas. Balões e flores de crepon colorido enfeitam o ambiente. A quadra esportiva está repleta de jovens dançando, conversando, bebericando ou comendo alguma coisinha. Entre eles, organizando a festa, estão os professores agora em outros tempos e ocupações. Nas barraquinhas, vê-se a maior parte deles com gestos e faces descontraídos. Alguns trajando chapéu a rigor. Enquanto vendem os produtos, conversam, tomam uma cervejinha e se distraem, embora uns já demonstrem cansaço. Desde as 16:00 horas estão na escola preparando a festa. Outros ali estiveram e se retiraram. Há também alguns poucos que não vieram. Lá estão eles e elas nas barraquinhas de 'Pipoca e Doces'; de 'Salgados e Caldos'; de ‘Canjica e Quentão’ e de ‘Cachorro Quente e Bebidas', como se lê nas tabuletas em cima de cada uma delas. Enquanto isso, na Sala de Leitura, transformada em Salão de Dança, Íris, uma professora mais jovem, auxiliada pela supervisora, ensaia os alunos que apresentarão a quadrilha. Há também os colegas que são o 'caixa' da festa: Arlete e Wander vendem as fichas para as barraquinhas, em uma mesinha na porta de entrada da Biblioteca. Em frente, na Sala de Multimeios, hoje Salão do Bingo, estão também Daisy, Helena e Cláudio, coordenando a brincadeira. No pátio, no meio da moçada, vê-se também dois outros mestres: Afonso, conversando com a namorada, que trouxe esta noite à escola, e Fábio, em uma roda de alunas. De vez em quando, dançando com uma delas. É Festa Junina na Escola Estadual."

Tradição brasileira, as festas juninas enfeitam e alegram as noites. Transfiguram os tempos e espaços escolares. Quebram limites e sugerem 
sua multiplicidade. São muitos os tempos de uma escola e diversificados seus rituais e ritmos que, apesar de demarcados e rígidos, são descontínuos e variados. Constituem-se de períodos cíclicos e lineares, ritmos coexistentes. Há atividades diárias, semanais, bimestrais, anuais que retornam, como as festas juninas, ao lado dos ritmos lineares próprios à seriação, aos graus de ensino e currículos direcionados para os momentos terminais das trajetórias escolares. ${ }^{1}$

Descrevendo um pouco mais os "tempos especiais" das escolas, em compasso de festa, há também as cenas do IV Festival de Música, da Escola Municipal. Voltemos à noite de 4 de Julho de 1998:

"No centro do pátio da escola, está montado um enorme palco decorado com cartazes da bandeira brasileira (é época de Copa do Mundo) e com duas caixas de som. Nas paredes das salas em seu entorno, embelezando o ambiente, vêm-se grandes murais coloridos, confeccionados pelos alunos, versando sobre o tema do evento: 'A construção da cidadania'. Alguns comentam: 'A escola está mais bonita hoje!' E os professores, onde estão eles? Na janelinha da secretaria, logo na entrada do pátio, estão Mara e Orlando, fazendo as vezes do caixa da festa: vendem as fichinhas para a compra dos alimentos e bebidas. Na cantina está um grupo maior, recebendo as fichas e passando aos 'fregueses' o caldo, a latinha

\footnotetext{
Como Lefebvre \& Reguliér (1992) analisaram, o tempo cíclico e o linear, noções que designam uma grande diversidade de fenômenos e fatos, são duas cadências coexistentes, cujos ritmos constituem relações de interferência, de dominação e rebelião de um contra o outro, numa unidade conflituosa, tal como observamos na interferência dos preparativos da festa junina sobre o andamento das aulas e dos conteúdos formais de ensino. A festa não pode esperar, tem um mês específico para ocorrer, representando uma temporalidade diversa da linearidade dos tempos de uma trajetória escolar anual e da seqüência dos graus de ensino. Trata-se ainda, de uma coexistência de tempos no qual os ritmos cíclicos e lineares se "penetran, pero en una lucha incesante, ya compromiso, ya perturbación". O tempo linear repetitivo designa "cualquier serie de hechos idênticos, separados por intervalo de tiempo más o menos grande". Em geral, o tempo linear é fatigante, monótono, enfadonho e intolerável, enquanto a volta de um ciclo é um acontecimento - a festa junina que revive a cada junho que chega. Como o evento, é algo que renova. Embora seja um recomeço, "siempre tiene la frescura de un descubrimiento y una invención", na expressão de Lefebvre \& Reguliér (1992, p. 263-5).
} 
de cerveja, os salgados. Na sala dos professores, estão Guilherme, Solange e Neuza, da equipe de História, coordenadores do evento. Eles orientam a comissão julgadora quanto à sua tarefa. No pátio, há ainda alguns professores que conversam entre si e com os alunos. Outros curtem os filhos, namorado, esposa, esposo, que vieram para o festival. Passados alguns minutos, sobem ao palco a vice-diretora e Joel, professor de Matemática, dando início à programação da noite. A certa altura, anunciam a entrada de uma dupla de colegas, Olavo e Fábio, para um número de canto, violão e flauta, parte do 'Festival de Talentos' que antecede a apresentação das músicas classificadas para a fase final do Festival de Música. Na seqüência, o professor Pedro e o diretor fazem uma cantoria que agita a platéia. Apresentam canções com refrões em rimas, satirizando a política brasileira, inspirados no tema do festival. E por aí a programação continua sem deixar qualquer dúvida: por iniciativa dos professores e direção da Escola Municipal, música e cidadania marcaram ali seu encontro, reinventando os tempos e espaços escolares. Uma fria noite de julho para ficar na lembrança."

Como se pode observar neste registro, dependendo da ocasião, professores são também músicos e poetas, compositores e intérpretes. Fazem rimas e cantorias alegrando a noite. Sobem em palcos ou ficam na platéia e nos bastidores, garantindo o sucesso do evento. Recriam os espaços e tempos escolares com o seu trabalho e iniciativa. Produzem os "tempos especiais" da escola: das festas, dos festivais, das feiras de cultura, gincanas e campeonatos. Celebram datas com festividades: dias das mães, dos pais, da família, dos estudantes, do professor e outros tantos. Fazem excursões, concursos e realizam eventos que extrapolam e enriquecem as interações e temporalidades educativo-pedagógicas, construindo na escola seus "tempos especiais" - os mais desejados, esperados, reivindicados e lembrados pelos estudantes.

Mas o que dizer desses momentos especiais e de suas modulações no conjunto da experiência docente dos tempos escolares? Como compreendê-los ou o que significam no cotidiano escolar?

Inexiste uma única medida ou significação para isso. Visto em um primeiro plano, como na festa junina e no festival de música, esses tempos 
podem representar um acréscimo de horas de trabalho para os docentes que os assumem. São atividades que exigem preparação, nem sempre cabíveis em seus horários ou jornadas habituais nas escolas, mesmo que se aproveite, para isso, o tempo das aulas, reuniões, intervalos de turnos, horários-janela e outros períodos escolares. Sendo insuficientes tais períodos, e para que tudo dê certo, ampliam as horas de trabalho dos professores, na escola e fora dela.

Os "tempos especiais", apesar de trabalhosos, geralmente são mais leves e descontraídos do que o período das aulas e outros da rotina escolar. Sendo tempos mais criativos e espontâneos, trazem do novo o frescor, abrindo-se a experiências outras e às emoções. São tempos marcados por um clima de festa, que instaura a "transitividade dos códigos", em gestos e comportamentos mais expressivos, conforme Meyer e Montes (1985) salientam. Festa pelos momentos de encontro, de coletiva construção e experiência compartida, quando os sujeitos se encontram de modo mais livre e solto, refazendo laços e relações. Tal como vimos nos gestos, nas conversas, nos rostos de professores e alunos nas cenas habituais das noites de festa junina e do festival de música, começando pelos trajes e pela postura de seus corpos: mais cuidados e belos, apropriados para a ocasião.

Ritual de inversão das relações sociais, criatividade, espontaneidade, prazer e alegria, reinvenção de símbolos, linguagens e gestos, visíveis nas cenas dos professores que sobem ao palco para a cantoria, reconstrução da memória e de festejos culturais, os tempos de festa têm também um sentido pedagógico. Abrem possibilidades educativas pelas trocas e situações que instalam, pela ressignificação dos tempos e espaços escolares, pela recriação da convivência entre os sujeitos da escola, trazendo-lhes novas experiências. ${ }^{2}$

2 Os "tempos especiais" escolares são, por vezes, momentos de celebração. De comemoração. Mas por que comemorar? Como Castro (1994, p. 93) salienta, o termo comemorar, compõe-se do prefixo cum-, que contém "três significações básicas que remetem para o homem no tempo e no espaço: a companhia (o homem e o outro); a simultaneidade (confluência de tempos diferentes) e a reunião (localizando num mesmo lugar homens e tempos diferentes)". Associado ao radical memorar, a companhia, a simultaneidade e a reunião se dão no memorar que "significa pôr na memória, lembrar, donde celebrar a lembrança de". Além disto, Castro destaca que há no comemorar um "apelo mais envolvente e com- 
Os "tempos especiais" são, portanto, parte das temporalidades escolares e expressam sua multiplicidade, incorporando-se aos calendários e horários. São tempos vividos com maior ou menor freqüência, duração e intensidade, dependendo da cultura da escola, da forma como a equipe de profissionais e cada um deles, individualmente, os significa e assume. Os "tempos especiais" integram a rítmica e a multiplicidade dos tempos escolares e, por conseguinte, a experiência temporal docente. Demarcam-se como tempos cíclicos, por vezes mais leves e curtos, porém extensos em significações, quando se tornam Kairós: momentos em que funcionários, diretorias, técnicos educacionais, professores e alunos neles estão por inteiro, vivendo-os como tempos plenos de sentidos.

Mas nem sempre são "especiais" os tempos docentes na escola. Sua base está em outros tempos: dos palcos das salas de aula.

\section{Tempos das aulas: relatos de experiências}

Foram férteis os relatos dos professores em nossas entrevistas sobre seus tempos de aulas. Comecemos com Guilherme, que salienta aspectos de sua experiência, comum a vários professores:

"Olha, na sala de aula você tem que ter um certo planejamento, por serem 50 minutos ou uma hora, não é? Você tem que ter planejamento para aproveitar bem. Ou seja, às vezes eu costumo colocar no quadro o que nós vamos fazer no primeiro momento, no segundo e no terceiro. As vezes o primeiro momento é de 10 minutos. E o que é ele? Nós vamos ver o assunto anterior, fazer uma revisão do anterior. No segundo momento, nós vamos ler um texto em voz alta

prometedor. [...] Comemorare está ligado a mnemon, que por sua vez provém do verbo grego mimneskein, que significa pensar em, fazer pensar juntos [...] Todo comemorar é um pensar com, um pensar juntos" (ldem, p. 103). Como então não dedicar partes dos tempos escolares aos rituais de comemoração? Como não celebrar acontecimentos e datas na escola, revigorando a memória e as raízes culturais de grupos e povos, trazendo à lembrança os sujeitos da história, reconstituindo seus feitos e histórias? Como não festejá-los, dando-os a conhecer às novas gerações do presente? 
e, no terceiro momento nós vamos fazer uma atividade com o texto ou vamos fazer uma discussão do texto. A aula é toda planejada, entre aspas. Então a gente tem uma noção do que vai acontecer e o aluno também. Eu sempre vou para sala com isso em mente. E, por incrível que pareça, os alunos entram nessa programação. [...] Mesmo que haja nas aulas muita coisa imprevisível, você tem que manter isso aí, porque senão você pode perder tempo demais com uma coisa, fica com uma atividade, não acelera e aí... Também por causa do nosso cotidiano. O tempo é muito precioso hoje, na sociedade moderna. E aí não tem como, se o professor e os alunos não souberem utilizar bem esse tempo na sala de aula, como é que ele vai utilizar o tempo na vida dele? [...] Para conseguir que eles entrem no meu ritmo eu ando a sala inteira, faço e peço para eles fazerem as coisas. Ah, é aquela coisa: eu nunca assento em uma sala de aula. Só assento quando eles estão em círculo. Aí eu assento para poder ficar no mesmo plano para falar com eles. É desgastante, mas eu faço isso direto. Agora à noite eu vou fazer e à tarde também já foi assim. Poderia ser mais tranqüilo, mas até que os alunos consigam pegar... À noite, é menos difícil porque eles já sabem, eles já têm o hábito de trabalharem em grupo. 'Vamos fazer discussão!' Eles fazem a roda rapidinho, começam a discussão rápido e têm uma certa objetividade já, mas isso é com o tempo. Porque eles já são alunos do segundo grau e já têm essa experiência e muitos já estudam comigo há muito tempo. Então já adaptaram a essa dinâmica de sala de aula."

No relato de sua experiência, Guilherme ressalta vários aspectos a serem analisados. O primeiro refere-se ao fato de que, em todas as escolas, existe um período estipulado para que as aulas transcorram, variando entre 45 e 60 minutos. Diante disso, aparece uma primeira dificuldade: como aproveitar esse tempo, ou como não desperdiçar, em sala de aula, este bem precioso na vida moderna, conforme Guilherme? E mais: como fazer com que os estudantes aprendam isto? Com essa colocação, o colega evidencia duas de suas preocupações: a do aproveitamento dos minutos das aulas e a de criar nos estudantes o hábito de bem utilizar o 
seu próprio tempo. A primeira constitui uma preocupação comum a outros docentes e a outra é mais particular. Neste caso, Guilherme confirma o argumento de que "aprendemos o tempo" e de que a escola participa dos processos socializadores em relação às pautas temporais dos grupos e culturas em que está inserida.

Frente ao problema do bom aproveitamento dos 50 minutos de suas aulas, observa-se um terceiro aspecto da experiência docente do tempo das aulas: ele precisa ser dividido, organizado, planejado, tal como Guilherme o faz, apesar de reconhecer as imprevisibilidades. Na medida em que é seu principal momento de trabalho com os estudantes, o professor deverá aproveitá-lo, pois configura os períodos definidos para o ensinar e aprender. Isso implica ocupar os alunos, impedindo que eles imprimam às aulas suas próprias cadências, ritmadas não pelo conhecimento, mas pelos interesses de adolescentes e jovens. O professor vê-se, pois, diante da necessidade de habituar os estudantes aos ritmos que considera adequados e planejados para o tempo da aula. E poderá consegui-lo, seja se desdobrando em todo o transcurso da aula, seja fazendo com que os alunos se habituem à sua dinâmica de aula, como na experiência de Guilherme, que sequer se assenta durante as aulas e tem vários anos de trabalho com algumas turmas.

Esse quarto aspecto subentendido na fala de Guilherme - a necessidade de ocupar os estudantes durante todo o período das aulas - é essencial e foi apontado por vários professores. Foram recorrentes, em nossas observações e falas, a necessidade e a preocupação docente no sentido de trazer e manter os alunos no "tempo da aula", o que explica a ocupação e a preocupação de inúmeros professores em idealizar e confeccionar material que interesse aos estudantes, preocupação / ocupação relativas a seus tempos nas aulas e fora delas, mesmo que lhes traga cansaço e desgaste.

Quanto ao aspecto da duração das aulas, definida pelo tempo-relógio salientado por Guilherme, Henrique tem também expressiva observação:

"Eu sinto que o tempo é muito espremido, quer dizer, todo espremido. O tempo que a gente cumpre mesmo é só na sala de aula. O outro, a gente vai negociando. Hoje eu posso fazer isso, amanhã eu posso fazer aquilo. O tempo é rígido, o compromisso da gente com a escola é o tempo em que a gente está na sala. Deu sete horas da manhã, eu tenho que 
estar na sala. E eu fico pensando que lá dentro, nessa aula de sete às oito é o meu tempo com o aluno."

Embora a experiência de Henrique seja comum a outros de seus colegas e distinta dos que descumprem horários sem maiores incômodos, para todos eles, os períodos das aulas estão fixados, mais que outros tempos de suas vidas, exigindo-lhes a adequação necessária. Além disso, como Henrique observa, o tempo da aula é o seu tempo com o aluno. Não pertence somente ao professor. É um momento partilhado, que ele deverá negociar com os estudantes, explicita ou implicitamente: questão evidenciada em vários dos relatos e depoimentos aqui registrados.

Por outro lado, a experiência do tempo das aulas, como de resto qualquer experiência temporal, envolve dimensões outras, que não a de sua duração quantitativa. Constitui-se, sobretudo, pelas temporalidades das relações, um tempo qualitativo, vivido como significação e sentimentos, presente na convivência entre professores e alunos. Toda a arquitetura dos rituais e atividades da sala de aula funda-se neste princípio. Tudo o que ali se constrói e processa inscreve-se nos tempos-movimentos das interações sociais.

Vejamos algumas colocações, como o relato de Íris, enfatizando a dimensão imensurável dos tempos docentes vividos nas salas de aula:

"O tempo, dentro da sala de aula, às vezes é comprido e às vezes é muito rápido. Depende da aula. Conforme a aula, conforme a turma. Conforme o que você está dando e a maneira como você encara a aula, parece que foram $10 \mathrm{mi}-$ nutos e o tempo às vezes não parece um tempo retilíneo. Às vezes parece cíclico. Não parece um tempo que no fim do dia eu estou morta não. Imaginei, quando eu peguei três turnos, que eu ia estar morta no final do dia. Mas não, eu não estou. O que ficou pra mim é que há na verdade, um ciclo de cansaço, não há uma sobrecarga, afinal. A sobrecarga eu faço se quiser, dependendo da aula que eu dou, como eu encaro a escola. Se está difícil, está doloroso, está cansativo. Os meninos não me obedecem, não sei mais o quê, e eu levo isso para outro lado e a aula não acaba. [...] Mas a aula que é boa, que é produtiva, em que todo mundo pode falar e se 
abrir, é outra aula. Aí não dá tempo. O tempo não dá tempo. Então, eu não sei não. E essa coisa de estar no fim do dia com um acúmulo de carga, puff, pra mim não é muito real não. Parece que o negócio é meio cíclico. Parece que é assim: eu me renovo dependendo da aula que eu dou. E não estou cansada no final da aula. Estou até com mais ânimo para a próxima aula. Não estou com sobrecarga. [...] Depois de uma boa aula, estou às vezes mais motivada para a próxima aula do que quando cheguei aqui na escola."

$\mathrm{Na}$ sua colocação, um dos aspectos salientados por Íris é o das implicações das condutas dos alunos sobre as vivências docentes do tempo das aulas, vivências associadas às significações desses períodos para uns e outros, professores e estudantes. As significações são entendidas como um elemento essencial, que dimensiona a própria questão do cansaço, analisada por ela nesta perspectiva - dos sentidos do vivido, e não apenas como um desgaste físico. O tempo da aula, como quaisquer outros momentos da humana experiência do tempo, não é somente um tempo homogêneo, matemático. Ele ultrapassa a dimensão quantitativa dos minutos, tornando-se mais breve ou longo, excessivo ou escasso, conforme os sentidos que atribuímos ao que nele vivenciamos. A duração de uma aula é experienciada não somente em minutos/relógio, mas como significações, como os sentimentos que nela vivemos, associados aos sentidos que lhe conferimos. Sendo assim, uma aula parece não ter fim, é um nunca se acabar, tanto quanto poderá ser rápida e produtiva, conforme o que representa para professores e alunos. O tempo das aulas é um tempo khronos, mas pode-se vivê-lo também como kairós, nas situações em que docentes e estudantes nele se realizam, envolvendo-se por inteiro em relações e atividades plenas de sentidos. Isso ocorre quando o "o tempo não dá tempo" ou quando "se os meninos pudessem ficar o recreio também, eles emendariam", nos dizeres de Íris e Paula.

Sendo a aula, fundamentalmente, uma relação social temporalizada, uma experiência intersubjetiva específica, os sentidos que alunos e professores lhes atribuem, e mediante os quais se comportam, estão em reciprocidade, constituindo parte das processualidades desses seus encontros de co-presença. Como Íris salienta, se os alunos não obedecem ou se não participam, a aula parece não ter fim. E "se está difícil, está doloroso, está cansativo.” Mas se eles participam, “ela é outra aula. 
Aí não dá tempo. O tempo não dá tempo". Por isso, “depois de uma boa aula" ela poderá sentir-se mais motivada para outra aula e mais animada do que quando chegou à escola. De outro lado, Íris observa que esse movimento, em que o professor se sente mais ou menos animado, mais ou menos cansado, dependendo do contexto das significações das aulas, configura uma temporalidade não linear, traduzida em "ciclos de cansaço". Aqui a colega evidencia um aspecto cíclico dos períodos das aulas, que extrapola à idéia do ciclo apenas como o retorno dos horários a cada dia e semana, repondo-se a cada turma, a cada turno. O tempo cíclico transparece, nesse caso, ligado à corporeidade, ao cansaço, que por sua vez não é apenas uma questão biológica, porque se associa às significações implicadas nos tempos das aulas. Quanto à idéia do tempo cíclico, ela reaparece aqui no sentido da possibilidade de renovação, do recomeço no qual a volta de um ciclo é sempre um acontecimento, conforme Lefebvre \& Reguliér (1992).

Complementando as considerações de Íris, vejamos o que Paula nos traz:

"Oh, os nossos alunos, eu tenho percebido que ao longo desses anos eles estão mais agitados, uma energia... Então como é que o tempo da aula passa? Há atividades em grupo em que às vezes eu já preparo a sala para receber os meninos. Se a gente os recebe para depois preparar a sala, é um tempo muito maior. Arrastam a carteira e fazem barulho. A gente tem que preparar a sala para receber os alunos nas atividades em grupo. E é assim: há aulas que passam super rápido, todos discutem, eles dão palpite, puxam uma coisa aqui e outra dali. Há outras em que a gente perde muito tempo chamando a atenção de um ou outro, porque querem avacalhar. E há aulas (porque a gente tem algumas turmas em que os meninos são muito acomodados, apagados) em que você pode falar 50 coisas que eles simplesmente ouvem. Não perguntam nada, não falam nada. Nós temos alunos esperando o tempo passar. [...] Então, geralmente, nessas turmas, o tempo para a gente parece que realmente demora muito mais a passar. Você tem um desgaste maior e um retorno muito menor. E há aulas em que, às vezes, se os meninos pudessem ficar durante o recreio também, eles emendariam." 
Além de retomar a discussão de que o tempo das aulas extrapola o seu período em horas, semelhante ao que Iris dissera, Paula realça outras dimensões de sua experiência do tempo. Uma delas refere-se aos momentos em que prepara o espaço para organizar os alunos e ganhar tempo. O outro é o do tempo que gasta, que perde, chamando a atenção dos alunos que "avacalham". Além desses momentos perdidos, Paula sente-se incomodada nas ocasiões em que os alunos ficam alheios, simplesmente "ouvem, não perguntam nada, não falam nada", segundo ela. Neste caso, seu desconforto não é porque eles "avacalham" a aula, mas porque estão indiferentes ao que se passa. Lembrando uma expressão popular, pode-se dizer que o aluno entra em sala, entra na aula, mas a aula não entra nele. É preciso trazê-lo a esse tempo a cada momento.

Dessa maneira, Paula reitera a questão do envolvimento dos alunos nos tempos das aulas, reforçando o que muitos professores disseram. Segundo ela, "eles não querem aula, mas não querem ficar longe da escola", observação que Luiza completou na entrevista da dupla, dizendo: "Eles vivem pedindo pra sair mais cedo e, quando saem, não saem da porta da escola. É a maior incoerência. A escola é um bom lugar, onde os meninos se sentem bem. A sala de aula não, a escola sim."

Em nosso convívio e escuta dos professores, essa foi a questão que mais se destacou na vivência docente dos tempos escolares: $o$ desinteresse do aluno, sua desmotivação e os comportamentos inadequados nas aulas, a indisciplina, segundo suas palavras. Tal problema tem hoje o mesmo nível de importância dos baixos salários, da qualidade de vida, dos sentimentos de desvalorização, baixa estima, desânimo e desesperança característicos de parte do professorado.

Seguindo em frente, vejamos esse relato de Henrique, para dele extrair outros traços característicos da experiência dos "tempos das aulas”. Ele expõe:

"O sentimento que eu tenho é angustiante, porque sinto que quero fazer muita coisa, mas não dou conta de fazer, inclusive, no momento estou trabalhando em três períodos. Eu passo o sábado e o domingo cuidando do meu tempo na escola. E eu acho isso importante para o aluno: se estou trabalhando com ele e dou um exercício hoje, eu quero entregar na próxima aula... É um tempo curtíssimo. Acho que 
24 horas é pouco. A gente tinha que ter mais tempo. Como a gente fala, o ideal é trabalhar num período só e ficar na escola a tarde toda ou em casa, para cuidar das turmas com que a gente está [...] Então é um tempo para cuidar do trabalho mesmo, de que a gente acaba descuidando, porque trabalha de manhã, à tarde e à noite. E o tempo de descansar? Eu estou sentindo muito isso: estou precisando de um tempo para mim. Para dormir, descansar, levantar cedo e ir tomar um banho de uma hora. Tomar café, ler um jornal e depois ir para a escola. Eu vejo esse tempo de me qualificar como pessoa e de qualificar o aluno. Essa falta de tempo de que a gente fala aí, vai desqualificando o nosso trabalho, desqualificando a nossa pessoa, o nosso aluno, o nosso colega. Então o meu sentimento é de angústia, é de não ter tempo de cuidar dessas coisas."

As considerações de Henrique, além de desvelarem, dos tempos cotidianos docentes, a falta, os tempos ausentes, contém a forte idéia de que o ato educativo é um tempo do cuidar. De igual forma, os tempos escolares e da sala de aula: são momentos de cuidar das crianças, dos adolescentes e jovens: tempos dos cuidados com a sua formação. Temporalidades que exigem calma, para serem levadas e vividas cuidadosamente. Para tanto, o profissional dos "tempos do cuidar" precisa se cuidar, certamente. Individual e coletivamente. E, se atentarmos ao que Henrique nos expõe, vê-se que ele não está pensando em longos tempos ou em grandes coisas. Suas colocações falam de um tempo para qualificar seu próprio trabalho, a si mesmo e ao aluno. Os tempos de seu desejo não são muito mais que isso: um tempo para as pequenas coisas, como se nota na seqüência de sua fala:

"É nesse sentido que eu falo que o nosso tempo tinha que ser maior, para a gente poder estudar, poder cuidar mais do aluno, do exercício dele com mais calma. A gente tem essa nuance, de estar trabalhando com o ser humano. Eu acho fundamental lembrar isso o tempo todo. O ser humano precisa de mais tempo para ele. Eu hoje não tenho tempo para a mãe, o pai, o amigo, ninguém. E o professor muitas vezes também não tem tempo de olhar para ele. Também não tenho 
tempo de olhar para os alunos, muitas vezes. Hoje eu fico pensando que já fiz muito esse discurso: 'Tem que dar conteúdo! Gente, não tem que dar conteúdo não! Eu tenho que olhar para o aluno, para a turma, para o grupo.' Então eu acho que é preciso um tempo mesmo. Um tempo para fortalecer a gente, a mim, professor. [...] Aí, na hora em que o aluno me chamar eu estarei aberto para ouvir. [...] Nós damos aula de manhã, de tarde e de noite: dormimos, acordamos e não paramos nem um momento para falar assim: 'Como você está? Me dá um abraço, um beijo?’ Não há tempo para se tomar uma cerveja gelada devagarinho, toma-se com tanta pressa que nem se acha prazeroso..."

Sem dúvida que a idéia do olhar a que Henrique se refere, em sua relação com os alunos, ressaltando sua precedência sobre os conteúdos de ensino, é pertinente. Nos encontros de co-presença entre humanos, em relações face-a-face, suas imagens e expressões corporais são essenciais para abrir possibilidades de entendimento. Mas, se as condições objetivas de tempo na vida dos professores impedem que eles se olhem e observem a si mesmos, como esperar que eles o façam quando diante de seus alunos?

As considerações de Henrique ressaltam, ainda, os vínculos entre os vários tempos que os docentes devem articular em sua vida cotidiana. Os tempos da sala de aula não estão isolados de outros momentos de sua vida, como também se associam aos demais tempos da escola. Se os docentes têm a maior parte de suas jornadas de trabalho tomada com a sala de aula e a escola, ficarão sem oportunidades para se cuidar e se renovar para estarem melhores nestes períodos. Há um comprometimento mútuo. $\mathrm{Na}$ medida em que estes tempos não estão prontos, mas são articulados pelos docentes, artífices de suas experiências, serão tempos tensionados, mutuamente prejudicados: ao invés de complementares e harmoniosos, provocarão desgaste e insatisfação.

Passando a outra das dimensões constitutivas dos tempos das aulas, observa-se que a flexibilidade pode ser também necessária durante uma aula, como Rogério evidencia nesta sua colocação:

"Aí você não pode trabalhar. Você faz um programa e às vezes tem que desprogramar esse tempo na sala de aula. [...] 
Isso acontece com freqüência. Você prepara uma aula e o clima da sala faz você mudar isso de imediato. Você encontra o grupo com problemas, nota que a turma está inquieta e tem que mudar o trabalho para você conduzir a turma, entendeu? [...] E, muitas vezes, você esbarra na questão disciplinar. $\mathrm{O}$ aluno às vezes também não tem aquela conduta que tem em casa. Não foi habituado a respeitar o silêncio, o momento do trabalho. Ele vem, às vezes, só para brincar. Ele não foi treinado, habituado a respeitar o horário, ou os próprios colegas. Então você passa a agir como disciplinário também em sala de aula [...] Então você tem que trabalhar isso na sala de aula, e tem que ser rápido para ter a turma nas mãos. Não digo em todas as turmas, há turmas em que você encontra uma homogeneidade, então é mais fácil."

Nas observações de Rogério sobre seus tempos de aula, várias questões sobressaem: a dos "corpos dóceis" que ele espera encontrar nos alunos; a incompatibilidade entre o habitus dos estudantes e a escola, analisada por Bourdieu e Passeron (1977); o desinteresse e desmotivação dos alunos nas aulas. Entretanto, delas enfatizamos os aspectos concernentes aos traçados rítmicos escondidos ou revelados nas interações sociais nos tempos da sala de aula. O professor surpreende-se porque encontra a turma em um ritmo diferente do que esperava. $\mathrm{O}$ grupo está fora do "pique" que precisava para executar o que ele programou; inexiste o "clima" e a cadência esperados. Nesse contexto, instalam-se as dificuldades que exigem sobre-esforço e agilidade. É preciso refazer a programação a tempo de "salvar" aquela aula: desprogramar o programado, naquele instante, com os jovens à sua frente e os minutos transcorrendo.

Alterar planos, fazer e refazer o andamento da aula, quando não todo o seu conteúdo e planejamento, são fatos comuns na rotina docente nos tempos das aulas. Mesmo havendo recursos punitivos de que lançar mão para o controle da turma - ponto crucial no período das aulas - parte do tempo e do trabalho docentes será perdido, trazendolhe incômodos diante da turma, da escola e de si mesmo, se não houver esse controle, que requer agilidade. A imprevisibilidade, uma das características dos tempos da sala de aula, exige, portanto, doses de vigor, inventividade e rapidez nas condutas docentes. 
Vistas por outro ângulo, a intersę̧ão dos ritmos das expectativas docentes e discentes e a própria rítmica diferenciada do conjunto dos estudantes de uma classe, impondo um e outro andamento e motivação à aula, demandam flexibilidade docente, agravada porque dentro de 45 minutos o docente deverá estar em outra turma, com novas características, interesses, necessidades, dificuldades e ritmos, como Henrique salienta. Os próximos 45 minutos exigirão um outro tipo de aula. Além disso, em um só dia de trabalho, muitos professores passam por mais de uma escola, turnos e coletivos estudantis, com variado perfil social, etário, cultural e rítmico. São diferentes contextos de trabalho e distintas cadências escolares, pois se sabe que manhãs, tardes e noites, ainda que em uma mesma escola, têm andamentos diversos, assim como os variados dias da semana e horários dentro dos turnos e turmas.

\section{Os tempos das aulas: recompondo a análise}

As falas dos professores revelam muitos aspectos das significações, da arquitetura e dinâmica de seus tempos de aulas, o período mais longo de suas vivências dos tempos da escola. Destaquemos e reafirmemos alguns deles:

- o tempo das aulas não pertence aos professores. Ao contrário: nas aulas, o tempo do professor é o tempo do aluno. Não há como separá-los. É um tempo intimamente partilhado entre docentes e discentes, construído na relação entre ambos;

- o tempo das aulas é um periodo fixo, rigidamente estipulado pelos horários e programações das escolas. As aulas têm um momento exato para seu início e término, independentemente dos interesses, necessidades e ritmos diferenciados das atividades, dos alunos e turmas;

- o tempo das aulas é um tempo a ser aproveitado, planejado, dividido, organizado. Deve-se ocupar os estudantes durante todo o período das aulas, preocupação destacada por muitos professores;

- é preciso trazer o aluno para o tempo da aula, pois muitas vezes eles escapam. Entram em sala, estão de corpo presente no tempo das aulas, mas esse tempo não está dentro deles. Como não é simples para os professores envolver os estudantes na aula e com a aula, eles gastam boa parte dos momentos de sua duração fazendo apelos aos alunos, 
chamando sua atenção para que entrem e se envolvam realmente com a aula;

- apesar de sua demarcação quantitativa, regulada pelo tempo do relógio, visível nos minutos definidos para o transcurso de cada aula, $a$ experiência do tempo das aulas, como de resto qualquer experiência temporal, é também qualitativa. Extrapola o aspecto quantitativo, de sua duração em minutos. É um tempo significado e significativo, dotado dos sentidos que os sujeitos atribuem às suas relações e práticas nestes períodos. E sendo assim, o tempo-significação poderá não corresponder ao tempo-duração, de natureza quantitativa. Por isso os mesmos 45 minutos de aula podem parecer o dobro disso ou a metade, dependendo do que neles se passa;

- o tempo das aulas é diverso, irregular e plural. Varia conforme o dia, o mês, conforme os horários das aulas (é diferente uma primeira aula de uma segunda-feira pela manhã e uma última aula de uma sexta-feira à noite). Varia conforme os tipos de turmas e suas respectivas rítmicas e ainda segundo os ritmos dos alunos ou grupos deles. Uma aula de Matemática depois de uma de Educação Física exige um tempo para os alunos acalmarem. De igual forma, são também diferentes a rítmica e as modulações temporais de uma aula com uma turma de adolescentes, de crianças ou de adultos;

- os tempos das aulas são marcados por imprevisibilidades. Embora seus rituais, rotinas e rítmicas se repitam em uma aula e outra, os imprevistos estão sempre colocados como possibilidade ou como fato. E assim sendo, cada aula é única. O tempo de cada aula é específico, singular, inusitado. E terá que ser construído. Nunca está pronto ou dado como um a priori.

- os tempos das aulas articulam-se com outros tempos da escola. É preciso combinar os tempos de reunião, os recessos, os "tempos especiais" com os períodos reservados às aulas;

- os tempos das aulas não se esgotam neles mesmos. Terão que ser preparados anteriormente, e serão avaliados depois de concluídos. Eles se estendem para além dos períodos dos professores em sala de aula, propriamente, seja como ocupação, seja como preocupação;

- os tempos docentes das aulas se articulam com os tempos docentes fora da escola. $\mathrm{Na}$ experiência dos professores é visível a imbricação dos tempos da escola em seus tempos privados. Questões da escola são trazidas à esfera da família, da vida doméstica, como também certas questões 
domésticas são trazidas aos tempos das aulas, sobretudo em uma categoria profissional predominantemente feminina.

Visto por um outro plano de análise, embora vividos, sentidos e significados de variadas formas, dependendo do/a professor/a, da turma, da escola, do turno, entre outros fatores, dois elementos ressaltam nos "tempos das aulas", constituindo-os como tal. De um lado, mesmo sendo fragmentados, eles são os períodos mais longos e constantes dos calendários e horários das escolas e das trajetórias escolares em seu conjunto. Nos moldes atuais, os "tempos das aulas", em geral entre quatro paredes de uma sala, são os períodos principais da rotina e dos currículos escolares. De outro, são tempos relacionais, de interações entre as gerações humanas em convívio no espaço escolar.

O tempo da aula é um encontro de co-presença de sujeitos sociais, no qual estão em jogo interesses e condutas docentes e discentes, sujeitos inscritos em temporalidades etárias, de gerações, em cadências rítmico-temporais diversas. Esses encontros constituem-se no contexto da ação de professores e alunos, movidos por diferentes lógicas e contêm aspectos de indeterminação e imprevisibilidade. O tempo da aula será um ou outro, dependendo dos acordos e negociações abertos ou velados, explícitos ou implícitos, que docentes e discentes efetuam permanentemente. Trata-se, ainda, de momentos de reciprocidade, em que os atores sociais referenciam mutuamente o sentido de suas condutas, em relações sociais que envolvem formalidades e informalidades. Aulas são tempos e contextos de sociabilidade.

Há também nos tempos das aulas gestos e palavras cadenciados. A chamada dos alunos costuma abri-los, seguida pela exposição das atividades do dia e dos conteúdos a serem desenvolvidos naquela aula. Há posturas rítmico-temporais específicas para cada momento das aulas, assim como para pedir a palavra ou para as atividades individuais e coletivas. Esta divisão do período da aula em pequenos tempos é uma das faces de sua ritualização e rítmica. Mas esses são apenas alguns aspectos da temporalidade das aulas. Que outros planos reforçar? A dimensão do instituinte - do tempo construído pelos atores sociais a cada dia, em cada turma, a cada aula - quando as temporalidades da convivência humana se revelam como cotidiana criação dos sujeitos sociais, mediante suas ações e relações, contextos de significações e ressignificações. 
Ao atuarem nos múltiplos tempos e espaços sociais, movidos por várias lógicas de ação, os atores sociais extrapolam o esperado, constituindo-se como sujeitos de experiência. Rompem a condição de indivíduos reduzidos a papéis. Em suas atividades cotidianas, individuais e coletivas, os sujeitos sociais reproduzem, tanto quanto produzem novas práticas em ações instituintes, reinventando temporalidades e espacialidades. Lembrando Thompson (1987), a experiência social da aula contém a ação de sujeitos sociais movidos por condicionamentos sociais e circunstâncias que regulamentam seus rituais e rítmicas, de um lado, e de outro, sujeitos que atuam sobre as circunstâncias dadas mediante seu sistema de significações.

Professores e estudantes "fabricam" o tempo das aulas, constituindo sua experiência escolar para além do instituído, não obstante os imperativos dos horários e de sua localização no calendário e no dia escolar. Na medida em que é "fabricação", cada aula é única e imprevisível. Nelas, espera-se o inesperado, conforme Laura nos dizia, referindo-se ao tempo da aula como um "jogo" em que parece faltar alguma peça, em que algo está fora do lugar, podendo-se alterar o quadro a qualquer momento.

A experiência do tempo da aula é um "trabalho" dos sujeitos sociais que nele se relacionam sob o comando, incerto, dos professores, visto seu lugar de poder no grupo. Sujeitos que articulam seus interesses com as representações interiorizadas e a regulamentação estabelecida para esses momentos. E, como todo contexto de relações sociais, os tempos das aulas envolvem negociação de sentidos, forças e interesses. E, também, articulações e tensões entre temporalidades, pois professores e estudantes se localizam em faixas etárias, ciclos de vida e gerações diferentes, em temporalidades distintas, com implicações de várias ordens, entre as quais a configuração de interesses etários e geracionais específicos.

Dito de outro modo, a experiência do tempo das aulas é uma obra dos sujeitos que articulam temporalidades coexistentes: os vários tempos escolares, as temporalidades do conhecimento, dos ciclos de vida e das gerações de professores e alunos, a rítmica das interações educativo-pedagógicas e, ainda, as temporalidades pretéritas e as perspectivas de futuro. A experiência do tempo das aulas é um "trabalho" dos sujeitos que articulam as lógicas que movem sua ação, de professores e alunos, 
na experiência escolar, atores sociais portadores de sentidos e interesses diferenciados. Essa é uma das razões pelas quais os períodos das aulas se diferenciam conforme alunos, turmas e turnos, tal como enfatizado pelos professores. Aulas são tempos polissêmicos.

Há ainda que reafirmar que a experiência do tempo das aulas, como de resto qualquer experiência temporal, envolve dimensões outras, que não a de sua duração quantitativa. Constitui-se, sobretudo, pela natureza das temporalidades das relações, um tempo qualitativo, vivido como significação e sentimento constitutivos da convivência entre professores e alunos. Toda arquitetura temporal, rituais e atividades da sala de aula fundam-se nesse princípio. Tudo o que ali se passa inscreve-se nos tempos-movimentos-significações das interações entre os sujeitos sociais alunos e professores. O tempo da sala de aula, como quaisquer outros momentos da humana experiência do tempo, não é somente um tempo homogêneo, matemático. Ele ultrapassa a dimensão quantitativa dos minutos, tornando-se mais breve ou longo, excessivo ou escasso, conforme os sentidos que atribuímos ao que nele vivenciamos. A duração da aula é experienciada não somente em minutos/relógio, mas como significações como os sentimentos que nela vivemos, associados aos sentidos que lhe conferimos.

Dos tempos docentes vividos nas aulas, há, finalmente um novo aspecto considerável: sua centralidade na construção de identidades docentes. Aulas são tempos fundacionais, são o primeiro momento em que os professores se constituem como tal. Tratam-se de temporalidades relacionais e contrastivas nas quais, em seus relacionamentos e contrastes, professores e alunos se mostram como nós e como eles. A relação professor/aluno é constituída e constitui posicionamentos sociais distintos. Instaura e é instaurada mediante diferentes lugares, posições e condições. Por ser assim, os tempos das aulas criam identidades. O lugar e a experiência de aluno e de professor têm origem e revelam-se por inteiro nos tempos e espaços das salas de aula, frente aos quais as demais jornadas e tarefas docentes são complementares. Professores tornam-se professores em suas relações e contrastes com os alunos nos contextos das aulas, temporalidades relacionais e contrastivas. E vice-versa.

Por outro lado, porque os tempos de sala de aula são construções dos sujeitos que neles "fabricam" experiências, na dinâmica de suas 
relações e contrastes, suas identidades são sempre processos de identificação. As identidades não são fixas e não estão dadas de uma vez por todas. Como muitos professores disseram, os alunos de hoje não são os mesmos de ontem, bem como a relação docente-discente. E porque os professores se constituem como tal, nessas relações, eles se modificam conforme os estudantes e as relações docente-discente se alterem. ${ }^{3}$

\section{Os tempos interstícios}

"São 21 horas de uma segunda-feira, 22 de junho de 1998. Os/as docentes vão chegando à Sala dos Professores e assentando-se nas cadeiras de madeira e na pequena poltrona em volta da mesa para a merenda: comem o bolo e pão de queijo, trazidos por Henrique e Luana, os professores responsáveis pelo lanche desse dia na escala do mês. O cafezinho veio da cantina da escola. Enquanto os professores e professoras se alimentam, a conversa é animada, envolvendo todo o grupo ou em sub-grupos: as últimas notícias da campanha salarial, a performance do Brasil na copa do mundo, os casos do viagra, os comentários sobre alguns alunos e turmas são os assuntos desta noite. Lourdes e Bruno, professores de História e Geografia, depois de lancharem, entram na Sala de Projetos (junto à Sala dos professores), onde conversam alguns segundos, saindo em seguida com mapas e fita de vídeo nas mãos. Bruno veste uma camisa com a frase: 'Temos que correr contra o tempo', camisa do Projeto

3 Nos termos de Dubet (1994), as identidades são "movediças", não são substâncias. Não são um ser. Identidades são também um "trabalho": os sujeitos as constroem em suas relações e contrastes, em suas experiências e temporalidades. As identidades sociais se produzem nas redes de sociabilidade em que os atores sociais se localizam e posicionam como sujeitos coletivos. Isso se desenvolve nos cenários das interações sociais, fluentes nos tempos e espaços de convivência humana, nos quais se fazem, desfazem e refazem as noções, representações e sentimentos de pertencimento e de não pertencimento, de semelhança e de diferença, de proximidade e de distância, do "nós" e do "eles", mediante posicionamentos e relacionamentos sociais, contrastividade e experiência de coletividades e grupos, como nas salas de aula. 
'Acertando o Passo' da Rede Estadual de Ensino de Minas Gerais. Neste momento, Rejane, depois de olhar se todos os colegas estão presentes, pede um minuto de atenção e anuncia: 'Hoje temos uma surpresa!', abrindo passagem para a entrada de Marina, vice-diretora, que tem nas mãos uma Cesta de Bebê. Marina dela retira um cartão, entregando-o a Eduardo que lê em voz alta as palavras de boas-vindas dos colegas a seu segundo filho, nascido há uma semana. Sorrindo, ele agradece e abre a cesta com a ajuda de Rejane e Raquel, em clima de afetividade e alegria. Depois de curtirem o presente, o diretor pede um momento à turma e diz: 'Precisamos combinar como será o horário da escola amanhã a noite, porque o jogo do Brasil na copa está marcado para as 16 horas. E se ganharmos... Vamos resolver o que faremos para avisar aos alunos.' O grupo discute e decide suspender as aulas. Terminada a conversa, o coordenador de turno bate o sinal, dizendo que já se vão 15 minutos do término do recreio. Sem mais demora, os professores se retiram para suas salas-ambiente, para as duas últimas aulas daquela noite."

Semelhante aos intervalos entre os turnos (da manhã para a tarde e da tarde para a noite) e aos momentos de chegada e saída da escola, recreios são interstícios dos tempos escolares em que os professores se encontram, momentos marcados por afetividade, espontaneidade e descontração, geralmente nas Salas dos Professores, espaço muito especial. Neles os colegas se vêem, se revêem e se mostram mais inteiros, revelando uns aos outros seus prazeres e dissabores quanto aos alunos, a escola, a Prefeitura, o Estado, a profissão. Ou mesmo quanto à vida pessoal, familiar, particular. Recreios são tempos em que os professores compartilham as alegrias e as dificuldades do ofício. E, dependendo do dia, podem transformar-se em rituais de festa e de dádiva, como na cena acima, quando os colegas ofertaram a Eduardo uma "Cesta de Bebê".

Os "tempos interstícios" são momentos de descanso e descontração em que se revêem os amigos ou se fazem amizades, quando os laços entre o grupo se estreitam. São também nesses tempos conjuntos que as diferenças afloram nas pequenas polêmicas e discussões, que deixam ou não ressentimentos, superados ou cristalizados posteriormente, 
tal como outros momentos coletivos dos docentes na escola. Recreios são uma ocasião para refazer energias. Como Ana, professora de Ciências, dizia, "recreios são um período pequenininho em que você vai relaxar de um tempo maior em que você se cansou, numa sala, atendendo ao aluno".

Momentos para se ler os murais da Sala dos Professores, atualizando-se sobre as novidades da escola, do Sindicato, da Secretaria de Educação, recreios servem também para avisos e pequenas reuniões para discussão e decisão sobre questões mais simples ou mais urgentes da escola. São ainda boas ocasiões para assinar o ponto, dar um telefonema ou resolver pequenas coisas, como se observa no registro acima.

Esses pequenos intervalos de folga, que os professores e alunos tanto prezam, são períodos esperados e desejados pelos docentes e discentes, pois quebram os ritmos da rotina das aulas. São curtos, minutos poucos, porém longos e extensos no que representam. E tanto quanto são leves, são fortes e, por vezes, intensos, pelas trocas e vivências que possibilitam.

Tempo coletivo, mas também individual, os recreios permitem algumas escolhas pessoais acerca de como aproveitá-los. E são períodos de relaxamento, que professores e alunos querem sempre prolongar. Como Priscila, professora de Matemática dizia, “de certa forma, é um pouco assim: a gente não tem muito tempo. $\mathrm{Na}$ medida em que pegou uma aula, você vai ter a folga de novo só no recreio. Aí é o único tempo que você tem. E tenta prolongá-lo."

Os "tempos interstícios" docentes nas escolas completam-se com os períodos de chegada e saída, com os "horários-janela" (um horário vago, entre uma aula e outra, no qual o professor não tem aula ou turma para assumir) e, em especial, com os intervalos entre os turnos escolares, lapsos nas rotinas do trabalho. São períodos que quebram a rítmica do exercício do ofício. E sendo assim, são ocasiões em que o professorado fica mais à vontade. Seus compassos, em geral na Sala dos Professores, são mais leves e soltos, marcados pelo ritmo do cafezinho, da prosa descontraída e das novidades do dia. São tempos de cadências irregulares, descontínuas.

Recreios são períodos mais relaxados e informais, de encontros e brincadeiras, mas podem ser também momentos de pequenos desentendimentos, vindos dos subterrâneos da convivência do conjunto e 
subconjuntos dos profissionais da escola. São ainda um tempo em que não faltam as reclamações, as insatisfações e os lamentos, como também a alegria. Nos recreios e demais interstícios do tempo, predominam os compassos pessoais, quando um e outro professor trazem as novidades e pedem notícias dos colegas, dos amigos comuns e de seus familiares. Por vezes, da cidade, do país e do mundo.

Semelhantes aos tempos coletivos, os interstícios dos horários das escolas, sendo momentos conjuntos, são períodos de encontro dos professores, quando eles se vêem, se conhecem e reconhecem no que têm de comum e de diverso. Por essa razão, são tempos de construção de identidades coletivas, tanto em relação ao magistério como um todo, quanto no que tange às particularidades das equipes de cada escola. Neles os professores tecem vivências comuns e partilham experiências, forjando laços de pertencimento. Neles dividem seus problemas, preocupações, indignações. Permutam desejos e projetos comuns, esperanças e desesperanças com o magistério, a educação e a escola. Nessas ocasiões, o grupo coletiviza suas dificuldades e perspectivas de vida docente e de profissão, (re)conhecendo-se como um grupo, em vivências constitutivas de identidades sociais. Neles vão lapidando modos de ser e viver a condição professor. Identidades dessusbstancializadas, porque fundadas em relações e experiências comuns aos pares, vivências singulares e contrastantes face aos demais grupos sociais, com posicionamentos e vivências outras. Identidades construídas em temporalidades e espacialidades, em vivências e contextualidades sócio-históricas do cotidiano da escola, que enredam vivências pretéritas, presentes e perspectivas de futuro. Lembranças e projetos comuns, costurados no presente.

\section{Considerações finais}

Como terminar uma discussão apenas iniciada? Ou mesmo, como concluir uma análise ainda inconclusa, senão por outras razões, porque os tempos vividos pelos professores nos variados tempos da escola não foram aqui esgotados? Eles contêm outras modulações. Como concluir uma reflexão ainda tão lacunar no campo dos estudos sobre a condição professor? Talvez o melhor caminho possa ser o de reafirmar idéias que 
nos permitam prosseguir e avançar na análise e compreensão dos tempos vividos pelos professores nos vários tempos da escola. Idéias que nos permitam melhor problematizar essas temporalidades em seus vínculos, modulações, limites e possibilidades. Nesse sentido cabe reafirmar que esses tempos só podem ser entendidos se observados em suas várias dimensões: de tempos instituídos e instituintes. De tempos quantitativos e qualitativos, exteriores e interiores, de tempos individuais e coletivos, khronos e kairós. E sobretudo, tempos vividos e regulados pelos imperativos temporais dos horários, calendários, relógios, mas também como tempos construídos pelos sujeitos que os significam e ressignificam, que os criam e recriam em suas relações e práticas no cotidiano da escola, como se observa em suas vivências e práticas lembradas em seus relatos. Tempos ancorados nas ambigüidades do próprio ofício docente nos tempos de hoje, tecido no paradoxo de suas dificuldades e alegrias, do bem estar e do mal estar docente, próprias aos limites e possibilidades dos processos de formação humana, responsabilidade primeira dos tempos da escola e de seus profissionais.

\section{Referências bibliográficas}

CASTRO, Manuel Antônio. Tempos de metamorfose. Rio de Janeiro: Tempo Brasileiro, 1994.

DUBET, François; WIEVRORKA, Michel. Penser le sujet: Colloque de Cerisy. [s.l.]: Fayard, 1993.

LEFEBVRE, Henry; REGULIÉR, Catherine. El proyecto ritmoanalítico. In: TORRE, Ramon Ramos (org.). Tiempo y sociedad. Madrid: Siglo Veintiuno de España Editores, 1992.

MEYER, Marlyse; MONTES, M. Lucia. Redescobrindo o Brasil: a festa na política. São Paulo: T. A. Queiroz, 1985.

THOMPSON, E. P. A formação da classe operária inglesa. Trad. Denise Bottmann. Rio de Janeiro: Paz e Terra, 1987.

TORRE, Ramón Ramos (org.). Tiempo y sociedad. Madrid: Siglo Veintiuno de España Editores, 1992. 
Resumo: O estudo analisa alguns enredos da experiência do tempo na vida de professores/as do Ensino Fundamental e Médio de Belo Horizonte (Brasil), entre 1997 e 1998. Através de entrevistas com esses professores e professoras e através de observações em escolas públicas, o trabalho discute as vivências dos tempos docentes e as significações que os mestres lhes atribuem, focalizando três planos temporais da escola: os tempos das festas; os tempos das aulas e os tempos interstícios. O trabalho conclui que estas vivências cotidianas dos tempos docentes e escolares são momentos nos quais, ao se relacionarem com seus alunos e entre si mesmos, os professores constituem maneiras de ser e de viver, identidades sociais e histórias - individuais e coletivas.

Palavras-chave: Experiência; tempo; professor; escola.

TIME NARRATIVES IN TEACHERS' STORIES

ABSTRACT: This paper analyzes some patterns expressed by first and second grade teachers' about their experience of Time. Through interviews with these teachers and observation of public schools, we discuss the teaching times and their meanings, as reported by the teachers, focusing on three temporal plans in school: the time of the parties; the time of the classes; the interstice time. The daily experience of the teachers in the school are moments in which, relating to students and between themselves, teachers constitute ways of being and living, social identities, and individual and collective histories.

KEYWORDS: Experience; time; teachers; school. 